\title{
A Critical Analysis on Advertising Banks Products and Services in Ghana
}

\author{
Shani Bashiru ${ }^{1} \&$ Alhassan Bunyaminu ${ }^{2}$ \\ ${ }^{1}$ School of Business and Management Studies, Accra Polytechnic, Accra, Ghana \\ ${ }^{2}$ Banking and Finance Department, University of Professional Studies, Accra, Ghana \\ Correspondence: Alhassan Bunyaminu, Banking and Finance Department, University of Professional Studies, \\ P.O. Box LG 149, Legon, Accra, Ghana. E-mail: albun7@gmail.com
}

Received: January 25, 2013

Accepted: February 20, 2013 Online Published: April 16, 2013

doi:10.5539/ijms.v5n3p117

URL: http://dx.doi.org/10.5539/ijms.v5n3p117

\begin{abstract}
The study investigates the fact that advertising has served as a dominant promotion mix tool in the banking sector in Ghana. The continuous reliance on advertising by financial institutions suggests an appreciable level of trust in it as a communication tool. The use of other measures to create awareness and attract customers in financial services has been used to a limited extent. More often, the quest to stir interest and inspire consumers to patronise a product or service in financial institutions has seen organisations latching on to advertising with other ways of influencing favourable customer decisions being jettisoned. This work explores other modes of winning customer buy in viewed in comparative terms with advertising. The data was analysed based on the objectives of the study. The main objective is to ascertain the extent to which advertisement leads to patronage of products and services of banks. Quantitative techniques were utilised in order to attain quantifiable understanding into the degree of impact of advertising on customer decision making in the banking sector.
\end{abstract}

Keywords: advertising, word of mouth, promotion mix, advertising media

\section{Introduction}

Advertising is a promotion mix tool that has deep seated roots in the formative period of recorded history. Archaeologists' in their curious efforts around the Mediterranean Sea have unearthed signs showcasing a variety of product offers. The Romans created awareness about impending gladiator fights by inscriptions on walls. In the era marking the golden age in Greece history, loud sounds of criers heralded the trade in cattle, arts and craft. One of the early commercials goes like: 'For eyes that are shining, for cheeks like the dawn. For beauty that lasts after girlhood is gone. For prices in reason, the woman who knows will buy her cosmetics from Aesclyptos.' (Kotler et al, 1999).

In this modern times however, advertising is sophisticated promotion machinery run on immense expenditure. Advertising figures attest to this standpoint. In the EU, advertising budgets have chalked annual figures of more than $\$ 75$ billion ( $€ 84$ billion).

Philip Kotler, Gary Armstrong, John Saunders and Veronica Wong (1999), in their book entitled Principles of Marketing, third edition, define advertising as any paid form of non-personal presentation and promotion of ideas, goods or services through mass media such as newspapers, magazines, television or radio by an identified sponsor.

Advertising is widely utilised by government and nongovernmental organisations, practitioners and social society organisations to t communicate to their stakeholders (Kotler et al, 1999).

Advertising if used at the right time and in an effective way can lead to the creation of awareness about a product and service and very importantly, create and build a brand. Coca Cola continues to advertise via television in the market in Ghana to consolidate its market position as the most preferred brand in the non-alcoholic beverage industry in the country.

\section{Literature Review}

This section is dedicated to the theoretical underpinnings of this work. 


\subsection{Various Perspectives of Advertising}

Advertising just like many concepts does not lend itself to a single definition. The definition of advertising is all the more blurred with the advent of integrated communication mix where various advertising tools are combined to capture the mood and imagination of targeted audiences. (Pick ton and Broderick, 2000). This notwithstanding, advertising can be defined in a style that is distinct from the rest of the elements of promotion mix. (Pick ton and Broderick, 2000).

Kotler et al. (1999) define advertising as:

"Any paid from of non-personal presentation and promotion of ideas, goods or services by an identified sponsor". (p. 793).

Kotler, in previous works points out the use of mass media by advertising. Mass media has the potential of reaching out to wide array of people at a point in time.

In their definition of advertising, Wells et al. (1992) posits that;

"Advertising is paid non-personal communication from an identified sponsor using mass media to persuade or influence an audience". (p. 10).

Crosier (1999) joins the fray by providing this definition of advertising.

"Communication via a recognizable advertisement placed in a definable advertising medium, guaranteeing delivery of an unmodified message to a specified audience in return for an agreed rate for the space or time used". (P. 266).

Any form of ideas, goods or services paid for by an identifiable sponsor to create awareness, persuade, remind/reassure or influence an audience is advertising (Chris Fill, 1999).

Any paid form of non-personal presentation and promotion of ideas, goods or services by an identified sponsor is an advertisement (Kotler et al., 2006).

From these definitions, some common themes which buttress the distinct traits of advertising are its non personal nature, the use of mass media and payment effected. These are fundamental to creating a distinction between advertising and the other promotion mix elements although it is not uncommon for the other promotion elements to exhibit some advertising characteristics.

\subsection{Types of Advertising}

Advertisements are designed for the achievement of various goals but they principally consist of two types: product and institutional.

\subsubsection{Product Advertisements}

This kind of advertisement is used largely to create awareness, inspire confidence in the product and call the customer to a specific action-to buy. It is very effective for new products being introduced in a competitive market with the aim of gaining early market share on sustainable grounds. Critical to the success of product advertisement is the need to hammer on the products distinct features that provides exceptional satisfaction to customer. This triggers the purchase decision of consumers in favour of the product and at the expense of competitors.

\subsubsection{Institutional Advertisements}

The focus of institutional advertisements is to create understanding and positive image for an organisation amongst it interested parties. It can be utilised proactively by having a conscious plan of promoting goodwill between the organisation on one hand and the stakeholders on another hand. When used in a reactive sense, organisations embark on institutional advertisements anchored by public relations to beat off and counteract a negative occurrence with an attendant adverse publicity.

\subsection{Designing an Advertising Program}

All the promotional elements require a carefully thought out exercise before implementation and advertising is no exception. Advertising involves enormous costs prompting the need for a display of dexterity in the development, execution and evaluation of the scheme (Hartley and Rudeclius, 2004).

\subsubsection{Identifying the Target Audience}

To craft a plausible advertising program, the advertisement must be tailored towards the needs and expectations of a targeted audience. Every facet of an advertising program must show mastery in understanding the physical 
and emotional needs of customers to ensure money well spent. Market research is critical here. To be able to build a deeper insight into customer dynamics, a market research should be embarked upon.

\subsubsection{Setting Advertising Goals}

Selecting advertising objectives allow marketers to know the kind of media to choose. Beside, the objectives serve as a standard for measuring the efficacy of the advertisement when implemented. For instance, when Globacom, operators of Glo telecommunications entered the market in Ghana in 2012, its goals was to create widespread awareness and attract early market share. This influenced the choice of media by Globacom which saw the company select Television advertising resulting in the significant inroads it made by winning considerable market share in its first three months of operations.

\subsubsection{Setting the Advertising Budget}

Since advertising has to be paid for, there is therefore a cost implication worth considering through a systematic effort of cost collation on every aspect of the advertising. Money is a scarce resource even in high liquidity firms and the need for planned expenditure in order to win approval by top management is important. Cost of advertising has been rising astronomically across the world. Against this backdrop, an advertising budget needs to be drawn based on real time but conservative figure to attract the buy in of approvers.

\subsubsection{Designing the Advertisement}

The central theme of the advertisement should be in tandem with the objectives of the advertisement. At any rate, the distinctive attributes of the product and the superior value it efforts should be a focal point in designing the advertisement.

\subsubsection{Message Attraction}

An advertising message should have the charm and the hypnotizing appeal of capturing the mood of targeted customers and influencing them to prefer the product when buying decisions are made. In advertising psychology, experts opine that, fear, sex and humour appeals.

\subsubsection{Creating the Actual Message}

This involves the work of creative artists and copy writers. Copywriters have the primary task of fashioning the text of the message in advertisement. This is usually a laborious and expensive endeavour and requires tact and craft. Nonetheless, it has to be emphasise that, getting it right here will provide the impetus for success.

\subsubsection{Selecting the Right Media}

The choice of media is usually influenced by the cost, coverage area and targeted audience. The electronic media includes television, radio and internet. Print media covers newspapers, billboards, and magazines. Every advertiser must select the advertising media in which to place its advertisement. Ghana has seen the proliferation of the mass media over the past two decades following the annulment of the newspaper and broadcasting laws in 1992. Companies usually have a couple if not several options to choose from but one overriding consideration should be the mass media that is widely used by the targeted consumers.

\subsubsection{Different Media Alternative}

Table 1. Media types, their advantages and disadvantages

\begin{tabular}{lllll}
\hline Medium & Advantages & \multicolumn{2}{l}{ Disadvantages } \\
\hline Television & $\checkmark$ & Reach extremely large audience & - & High cost to prepare and run advertisements \\
& $\checkmark$ & Uses picture, print, sound and motion effect & - & Short exposure time and perishable message \\
& $\checkmark$ & Can target specific audiences & & Difficult to convey complex information \\
\multirow{5}{*}{ Radio } & $\checkmark$ & Low cost & & \\
& $\checkmark$ & Can target specific local audiences & No visual element \\
& $\checkmark$ & Advertisements can be placed quickly & - & Short exposure time and perishable message \\
Magazines & $\checkmark$ & Can target specific audiences & Difficult to convey complex information \\
& $\checkmark$ & High quality colour & & \\
& $\checkmark$ & Long life of advertisement & Long time needed to place advertisement \\
& $\checkmark$ & Advertisement can be clipped and saved Can convey & & Relatively high cost \\
& complex information & Competes for attention with other magazine features
\end{tabular}




\begin{tabular}{|c|c|c|c|}
\hline \multirow[t]{2}{*}{ Newspapers } & $\begin{array}{l}\checkmark \\
\checkmark \\
\checkmark \\
\checkmark\end{array}$ & $\begin{array}{l}\text { Excellent coverage of local market } \\
\text { Advertisements can be placed and changed quickly } \\
\text { Advertisements can be saved } \\
\text { Quick consumer response }\end{array}$ & $\begin{array}{l}\text { - } \quad \text { Advertisements compete for attention with other } \\
\text { newspaper features } \\
\text { - } \quad \text { Short life span } \\
\text { - } \quad \text { Poor colour }\end{array}$ \\
\hline & \multicolumn{3}{|c|}{ Low cost } \\
\hline Internet & $\begin{array}{l}\checkmark \\
\checkmark \\
\checkmark\end{array}$ & $\begin{array}{l}\text { Video and audio capabilities } \\
\text { Animation can capture attention } \\
\text { Advertisements can be interactive and link to advertiser }\end{array}$ & $\begin{array}{l}\text { - Animation and interactivity require large files and } \\
\text { more time to "load" } \\
\text { - } \quad \text { Effectiveness is still uncertain }\end{array}$ \\
\hline Outdoor & $\begin{array}{l}\checkmark \\
\checkmark \\
\checkmark \\
\checkmark\end{array}$ & $\begin{array}{l}\text { Low cost } \\
\text { Local market focus } \\
\text { High visibility } \\
\text { Opportunity for repeat exposures }\end{array}$ & $\begin{array}{l}\text { - } \quad \text { Message must be short and simple } \\
\text { - } \quad \text { Low selectivity of audience } \\
\text { Criticized as a traffic hazard }\end{array}$ \\
\hline \multirow[t]{2}{*}{ Direct mail } & $\begin{array}{l}\checkmark \\
\checkmark \\
\text { me }\end{array}$ & $\begin{array}{l}\text { High Selectivity of audience } \\
\text { Can contain complex information and personalized } \\
\text { ges }\end{array}$ & $\begin{array}{ll}- & \text { High cost per contact } \\
- & \text { Poor image (junk mail) }\end{array}$ \\
\hline & $\checkmark$ & High-quality graphics & \\
\hline
\end{tabular}

SOURCES: William F. Arens, Contemporary Advertising, $8^{\text {th }}$ ed, (New York: McGraw-Hill/Irwin, 2002), p. 291; and William G. Nickels, James M. McHugh, and Susan M. McHugh, Understanding Business, $6^{\text {th }}$ edition (Burr Ridge, IL; McGraw-Hill/Irwin, 2002), p.493.

\subsection{Theories of Advertising}

Proponents of advertising have been vehement in describing advertising as a potent marketing communication tool. However, advertising has it ardent critics who have latched on every opportunity to portray it as a spent force. Prominent among these experts who have exhibited support for advertising and raise criticisms against advertising are Jones (1991; Fill 2005).

\subsubsection{The Strong Theory of Advertising}

Advertising has often been associated with efficacious ability to inform, remind, differentiate and favorably persuade customers to buy a product and engage in repeat purchases. It also plays an influential role in positively changing the knowledge, attitudes, beliefs or behavior of target audience (Jones 1991; Fill 2005). According to Jones (1991), exponents of this standpoint hold that advertising has some inherent persuasive powers that can ignite buying behaviour of a product that has not been tested previously. Further, repeat and continues buying over the long haul can be secured through the palpable influence of advertising. Based on the strong theory, advertising is credited with the potent force of building brand loyalty leading to a steady flow of sales revenue (Belch 2001). These positive shifts are achieved on the crest wave of manipulative and psychological techniques, which are deployed in customer minds for maximum advantage. Advertising also rides on the hierarchy of effects model, where sequential steps of buyer's decision making processes are stimulated by timely and suitable promotional messages.

According to Pickton, D. and Broderick A. (2005) advertising can be summarized as a highly convincing promotional tool which works by: Persuading customers to buy, creating and refreshing brands, differentiating between products and generating and increasing sales revenue.

\subsubsection{The Weak Theory of Advertising}

There is an upsurge in the number of experts who argue that the strong theory is a far cry from empirical realities. Notable amongst these array of critics is Ehrenberg (1988; 1979), who posits that a consumer's pattern of brand purchasing behaviour is driven more by habit than by exposure to promotional messages.

The framework espoused by Ehrenberg $(1988 ; 1979)$ is the Awareness-Trial-Reinforcement (ATR) framework. Awareness is required before any purchase is contemplated, although the elapsed period between awareness and action may vary in duration with some being very short or very long. In connection with the early adopters who have gotten the spark to try a product, a trial purchase constitutes the next phase. This may be stimulated by retail availability as much as by advertising, word-of-mouth recommendation or personal selling stimuli. Reinforcement follows to maintain awareness and trigger reassurance to propel the customer to repeat the pattern of thinking and the buying behavior and to cement the brand in the repertoire for occasional purchase activity. Advertising's role therefore is to breed brand familiarity and identification (Ehrenberg, 1997).

Following on from the original ATR model, (Ehrenberg, 1974), various enhancement have been suggested. However, Ehrenberg (1974) added a further stage in 1997, referred to as the nudge. He argues that some 
consumers can 'be nudged into buying the brand more frequently (still as part of their split-loyalty repertoires) or to favor it more than the other brands in their consideration sets'. Advertising need not be any different from before; it just provides more reinforcement that stimulates particular habitual buyers into more frequent selections of the brand from their repertoire.

According to the weak theory, advertising is capable of improving people's knowledge, and so is in agreement with the strong theory. In contrast, however, consumers are regarded as selective in determining which advertisements they observe and only perceive those which promote products that they either use or have some prior knowledge of. This means that they already have some awareness and insights of the characteristics of the advertised product. It follows that the amount of information actually communicated is limited. Advertising, Ehrenberg (1997) continues, is not potent enough to convert and convince people who hold reasonably strong beliefs that run counter to those portrayed in an advertisement. The time available (thirty seconds in television advertising) is not enough to bring about conversion and, when combined with people's ability to switch off their cognitive involvement, there may be no effective communication. Advertising is often employed as a defence, to retain customer and to increase product or brand usage. Advertising is used to reinforce existing attitude not necessarily to drastically change them.

Unlike the strong theory, this perspective accepts that when people say that they are immune to the influences of advertising they should be right. It also assumes that people are not apathetic, but capable of high levels of cognitive processing.

In summary, the strong theory suggests that advertising can be persuasive, can generate and secure long-run purchasing behavior and can increase sales. The weak theory suggests that purchase behavior is based on habit and that advertising can improve knowledge and reinforce existing attitudes. It views consumers as active problem solvers who do not rely on advertising to initiate and complete a buying decision.

\section{Research Design}

This study is quantitative in nature. The fundamental objective is to attain quantifiable insights into the degree to which advertisement influences buying decisions of banks products in Ghana capitalising on statistical tools for analysis and findings.

Targeted respondents include customers of the banks selected in this work. For further numerical understanding of the role advertisements play in luring customers, key bank officials are earmarked for purposes of gathering information about their viewpoints on the power of advertisements to attract customers. In both cases, data acquired will be subjected to numerical analysis.

The use of questionnaire constitutes the basic research tool for gathering data in this study. In an attempt to achieve the objectives of this project, various thematic areas are enshrined in the questionnaire such as Socio-demographic attribute of targeted respondents, identification of the promotional mix used by the company, nature, type and content of advertisements, the relationship between advertising and the customer patronage of the company's product and services and whether advertising plays an influential role in consumer buying behaviour of the bank's products and services.

\subsection{Sampling for the Study}

It is an arduous task to get bank employees to respond to research questions in Ghana. The difficulties emanates from the fact that, research work in the banking sector in Ghana is a rarity, a situation accentuated by ethical concerns associated with divulging banking information. In view of the quantitative nature of the study, sizeable sample of 70 respondents were targeted. Qualitative research is normally underpinned by big samples to facilitate representation and support replication of findings, conclusions and recommendations. The sample may rather look quite low, but it is justifiable because the issue at stake is quite specific and does not need the views of too many people to justify it. Quite apart from that the promotional issues and the wellbeing of banking are inextricably separable.

\subsection{Sampling Procedures/Techniques}

Combinations of sampling techniques used in order to attain the goals of this study were purposive, convenient and snowball. In the light of the hurdles that litter the path of securing respondents on issues concerning financial institutions such as banks, a meticulous effort was made to select respondents who were prepared to offer relevant information. Consequently, non-probability sampling procedures such as purposive and convenient sampling were employed to acquire data from managers and employees of the banks. Snowball sampling technique was employed to select the respondents among clients. At the banking halls customers were approached and those that showed readiness to serve as respondents were given questionnaires to complete. The 
customers, upon completion of the questionnaire were asked to assist in getting another customer to fill the questionnaire, an approach that allowed the researchers to identify a pool of willing customers and also the operationalisation of the snowball technique. Bank Managers and employees of the banks were approached and some persuasion was done to get them join the wagon of respondents despite the fact that, they clearly understood the objectives of this work.

\subsection{Sources of Data}

Secondary data was collected through the review of relevant literature contained in academic journals. The essence was to scrutinise published literature on advertisement and its effects on banking business. The literature reviewed anchored the theoretical perspectives of this work.

Original data was gathered through questionnaires containing close ended and open-ended questions. Some informal discussions had also been done with some of the top management officials from the banks. The use of these techniques allowed well measured as well as detailed responses to ascertain the impact of advertisements on patronage of services of the banks.

\subsection{Data Collection Techniques}

The procedure for data collection included designing the instrument, pre-testing of instruments. The researchers were directly responsible for the entire data collection; however, four field assistants were recruited and trained on the scope of the study, the content of the instrument, ethics in research and other relevant issues such as completing survey questionnaires. The training also included a pre-test of all the instruments used for the study. The lessons learnt from the pre-testing were used to check for consistencies and this helped to finalize the instruments and other logistical requirements for the study.

\subsection{Data Analysis}

This study is based on quantitative approach. It examines the relationships between a dependent variable and a number of explanatory variables, in this case, the extent of advertisement and its impacts on the patronage of the services provided by the banks. Inferences were made based upon the outcomes of the reactions between independent variables (advertisement) and dependent variables (patronage of goods and services). Correlation matrix was used to determine the relationship among the independent variables (patronage of goods and services) to help reduce the dimensionality of the data.

The Simple t-test was used to draw comparisons on the extent to which the rural and the universal banks uniquely react to the advertisement and the promotional activities.

Also grading of the types of promotions as factors that best attract the customers or best sell the services or the products of the banks was made. Descriptive Statistics, Bar Charts and tables were used to explore the pattern of the data. The statistical analyses were done using version 19 of the SPSS.

\section{Results of the Analysis}

The data was analyzed quantitatively with the use of multiple regression to establish the relationships among individual variables' contributing to the prediction of advertisements, Pearson Correlation Coefficient and Chi Square Test for determining the relationships between and among variables and the simple t-Test was used to compare gender and types of bank on the issues. Tables and bar charts were used to provide the pictorial view of the data and inferences were drawn based on the analysis.

The analysis also covers the types of advertisement, the products and services of the banks, the challenges of the banks' in connection with advertisement in the country.

Per this work, five (5) banks were covered in the study; these are The Ghana Commercial Bank with $24.8 \%$ of the respondents, Merchant and Barclays Banks 27.8\% each, South Akim Rural Bank 6.0\% and the Upper Manya Kro Rural bank $13.5 \%$. The Universal banks were three and the respondents from them constituted $80.5 \%$ whilst the rural banks were two and represented $19.5 \%$ of the customer respondents. 
Table 2. Classifications of the banks according to names and types

\begin{tabular}{llll}
\hline Bank's Name & \multicolumn{2}{c}{ Bank Type } & Total \\
\cline { 2 - 3 } & $\begin{array}{l}\text { Rural } \\
(\%)\end{array}$ & bank & Universal bank (\%) \\
\hline Ghana Commercial Bank Ltd & & 24.8 & $\mathbf{2 4 . 8}$ \\
Merchant Bank Ghana Ltd & & 27.8 & $\mathbf{2 7 . 8}$ \\
Barclays Bank of Ghana Ltd & & 27.8 & $\mathbf{2 7 . 8}$ \\
South Akim Rural Bank Ltd & 6.0 & & $\mathbf{6 . 0}$ \\
Upper Manya Krobo Rural bank Ltd & 13.5 & & $\mathbf{1 3 . 5}$ \\
\hline Total & $\mathbf{1 9 . 5}$ & $\mathbf{8 0 . 5}$ & $\mathbf{1 0 0}$ \\
\hline
\end{tabular}

Source: field data, 2012

\subsection{Socio-Demographic Variables of the Customers}

The ages of respondents were captured as follows: Those up to 18 years were $18.0 \%$, those in the 29-39 brackets were $27.8 \%$, age group of $40-49$ was $45.9 \%, 50-59$ were $7.5 \%$ and the 60 or + were $0.8 \%$.

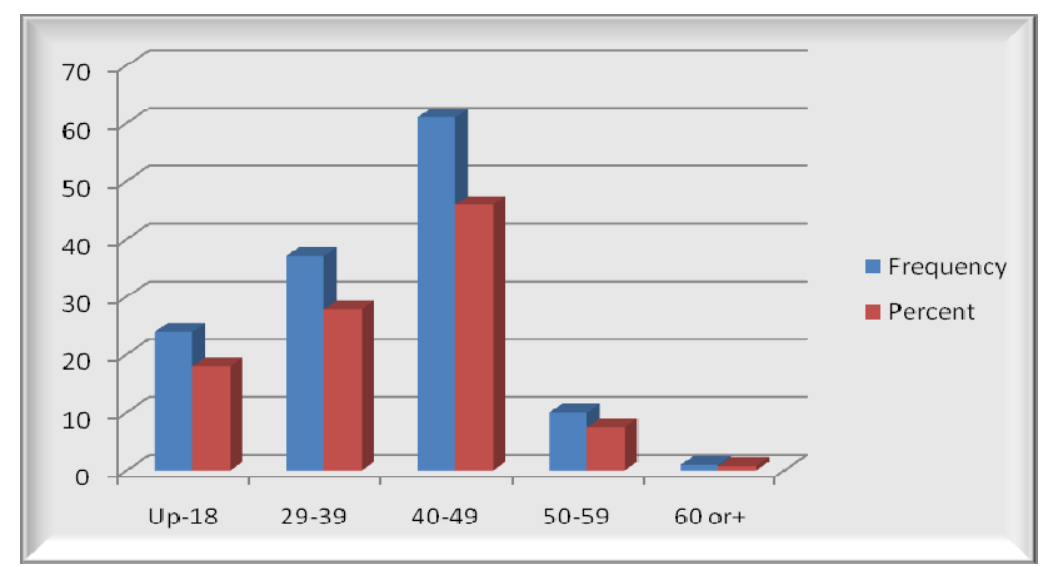

Figure 1. Age group of customers

Source: field data, 2012.

Table 3. Sex of the customer respondents

\begin{tabular}{lll}
\hline Sex & Frequency & Percent \\
\hline male & 84 & 63.2 \\
Female & 49 & 36.8 \\
Total & $\mathbf{1 3 3}$ & $\mathbf{1 0 0}$ \\
\hline
\end{tabular}

Source: field data, 2012.

The male female representation was $63.2 \%$ and $36.8 \%$ respectively. With the marital status, singles constituted $52.6 \%$, married couples were $43.6 \%$ whilst divorced and widowed were $3.8 \%$. 


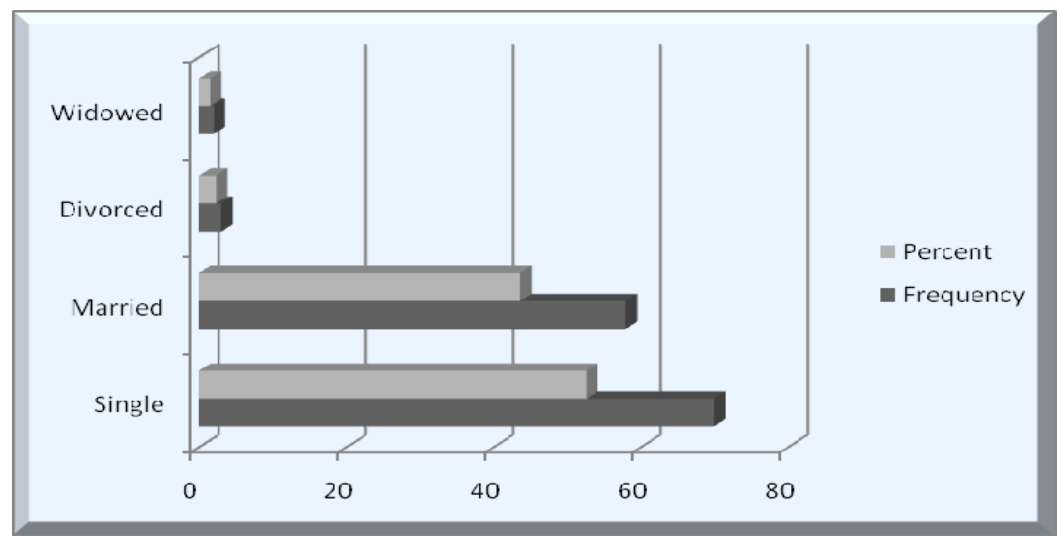

Figure 2. Marital status of the customer respondents

Source: field data, 2012.

In all, $46.5 \%$ of the respondents who constitute the majority have had tertiary education, secondary education followed with $23.3 \%$. The vocational training and teacher/nurse training education were $9.0 \%$ and $9.8 \%$ each whilst the basic education holders were $11.3 \%$.

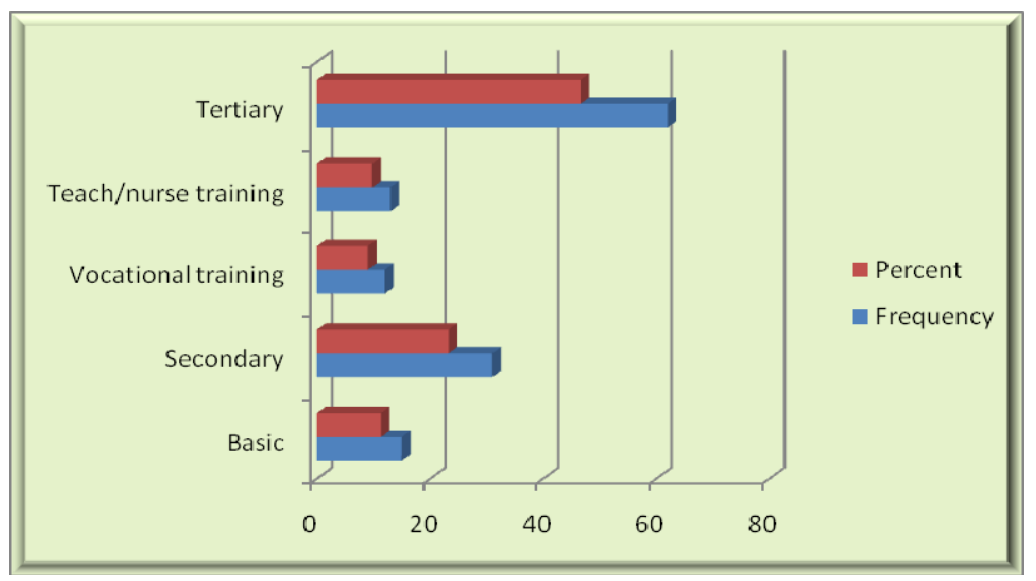

Figure 3. Highest level of education

Source: field data, 2012.

\section{Sources information about the banks}

Data analysis shows that, $30.5 \%$ as opposed to $69.5 \%$ says they get bank products information on the radio. This means radio is more heard if compared to television. Newspaper scored $18.3 \%$ of positive responses as against $81.7 \%$ who declined response, but it was higher than television. The information that respondents received about banks from third parties (word-of-mouth) was rather higher than any of the mass media associated with advertisement. By inference, bank products and services attract favourable customer consideration through word of mouth as a single factor. What is more striking is about how the respondents got to know of the banks is that more than half $55.7 \%$ as opposed to $44.3 \%$ saw the bank in the community and that it is not as a result of any advertisement that they got to know about the bank. 
Table 4. Sources of information about the banks

\begin{tabular}{llll}
\hline Item & Yes & No & Total \\
\hline TV advertisement & 16.2 & 83.8 & $100 \%$ \\
Radio advertisement & 30.5 & 69.5 & $100 \%$ \\
Newspaper advertisement & 18.3 & 81.7 & $100 \%$ \\
Word of mouth & 41.3 & 58.7 & $100 \%$ \\
I just saw it in the community & 55.7 & 44.3 & $100 \%$ \\
Total & $\mathbf{1 6 2}$ & $\mathbf{3 3 8}$ & $\mathbf{5 0 0 \%}$ \\
\hline
\end{tabular}

Source: field data, 2012.

Expressing the values obtained under yes for each of the information sources as a percentage, TV advertisement contributed $10 \%$, and thus, the least contributor, Newspaper advertisement made $11 \%$ and thus, the second least contributor, Radio advertisement made $19 \%$ as the third least contributor, Word of mouth made up of $25 \%$ and was adjudged the second best contributor and finally, with a percentage of 34\%, "I just saw the bank in the community" emerged as the best source of information about the banks. It can be concluded that there exists broad disagreements amongst respondents about the means of advertisement with the exception of "I just saw the banks in the community" and word of mouth.

Giving details about how they got to know about the bank, 15.4\% said information was received through a relative who transacts business with the bank; $25.0 \%$ indicated that it was through an advert on the radio, $49.0 \%$ indicated it was through a Friend, whilst $8.7 \%$ got banking information via enquiries. This further cements the position that word of mouth remains a solid source of information to banks clients.

Table 5. How you got to know about your bank

\begin{tabular}{lll}
\hline Item & Frequency & Percent \\
\hline Family relations & 16 & 15.4 \\
Heard their adverts on radio & 26 & 25.0 \\
Through a Friend & 51 & 49.0 \\
Through enquiries & 9 & 8.7 \\
$\mathrm{~N} \backslash \mathrm{A}$ & 2 & 1.9 \\
Total & $\mathbf{1 0 4}$ & $\mathbf{1 0 0}$ \\
\hline
\end{tabular}

Source: field data, 2012.

\subsection{Reasons Operating with the Banks}

On the reasons why the respondents are operating with the banks $67.5 \%$ said they transact business with the bank to save money for future use as compared to $32.5 \%$ who opposed. In all, $34.5 \%$ as opposed to $65.5 \%$ operated with the banks to attract business loans. Also, $47.3 \%$ as against $52.7 \%$ opined they conducted business with banks using current accounts in order to facilitate the payment of their monthly salaries. In summary, $15.1 \%$ as against $84.9 \%$ had the intention to operate bonds: Treasury bill and other short and long term savings instruments. Interestingly, $65.2 \%$ as against $34.8 \%$ did so for money transfer purposes.

Table 6. Reasons for operating with the banks

\begin{tabular}{llll}
\hline Column1 & Yes & No & Total (\%) \\
\hline To save with the bank to accumulate money for future use & 67.5 & 32.5 & $\mathbf{1 0 0}$ \\
To be offered loans for business & 34.5 & 65.5 & $\mathbf{1 0 0}$ \\
Current accounts for business transaction and receive pay & 47.3 & 52.7 & $\mathbf{1 0 0}$ \\
To operate bonds: T-bill and other short and long term savings & 15.1 & 84.9 & $\mathbf{1 0 0}$ \\
For money transfer purposes & 65.2 & 34.8 & $\mathbf{1 0 0}$ \\
Total & $\mathbf{2 2 9 . 6}$ & $\mathbf{2 7 0 . 4}$ & $\mathbf{5 0 0}$ \\
\hline
\end{tabular}

Source: field data, 2012. 
The most important reason for which the respondents deal with the banks had to do with ease of access which represented $42.0 \%$. Low interest rate was a significant factor that enticed the respondent to operate with the banks accounting for $13.4 \%$. The quality of general services also scored $19.3 \%$. Some other reasons were what they described as high rate savings account, foreign currency account $9.2 \%$ and import finance 7.6 as detailed.

Table 7. Products and services that enticed customers to operate with the banks

\begin{tabular}{lll}
\hline Item & Frequency & Percent \\
\hline Accessibility & 50 & 42 \\
Low interest rate & 16 & 13.4 \\
General banking services & 23 & 19.3 \\
Import finance & 9 & 7.6 \\
Superiority & 1 & 0.8 \\
Loan offering & 2 & 1.7 \\
High rate saving account, foreign currency account & 11 & 9.2 \\
None & 5 & 4.2 \\
Primary services & 2 & 1.7 \\
Total & $\mathbf{1 1 9}$ & $\mathbf{1 0 0}$ \\
\hline
\end{tabular}

Source: field data, 2012.

On whether it was the advertisement that made respondents to operate with their banks, $68.8 \%$ affirmed whilst $31.2 \%$ rejected. Further, on whether it was the advertisement that made other people to operate with the banks $41.3 \%$ as opposed to $58.7 \%$ agreed. This means majority of respondents neither agreed that advertisements attracted them to work with the banks nor other people. When asked whether the banks advertise at all, almost all the respondents $90.8 \%$ as opposed to just $9.2 \%$ affirmed the notion. On whether advertisement of the bank has any positive association with the extent of the patronage with them $78.0 \%$ as against $22.0 \%$ were affirmative. This means the most of the respondents think that adverts are doing well in promoting the products and services of the banks.

Table 8. Assessment of the influence of bank advertisements

\begin{tabular}{llll}
\hline Item & Yes & No & $\begin{array}{l}\text { Total } \\
(\mathbf{\%})\end{array}$ \\
\hline Adverts made you to operate with your bank & 31.2 & 68.8 & $\mathbf{1 0 0}$ \\
Adverts made other people to operate with the bank & 41.3 & 58.7 & $\mathbf{1 0 0}$ \\
$\begin{array}{l}\text { Do banks make advertisement at all } \\
\text { Has bank advert any positive association with the patronage with their }\end{array}$ & 90.8 & 9.2 & $\mathbf{1 0 0}$ \\
$\begin{array}{l}\text { products and services? } \\
\text { Total }\end{array}$ & 22 & $\mathbf{1 0 0}$ \\
\hline
\end{tabular}

Source: field data, 2012.

For those who agreed that advertisements influenced their decision to operate with the banks, $25.6 \%$ said the extent to which it occurs was very high, $65.1 \%$ said it was high and $9.3 \%$ said it was somehow high. For those who indicated that adverts make other people to do business with the banks, 32.1\% said the extent to which this occurred was very high, $53.6 \%$ indicated it was high, whilst $14.3 \%$ pointed it was high. On the extent of adverts undertaken by the banks, $11.7 \%$ believed it was very high, $29.2 \%$ felt it was high, $36.7 \%$ indicated that it was somewhat high. On the contrary, $20.8 \%$ declared it was not high whilst some $1.7 \%$ scripted it was not high at all.

Table 9. Influence of adverts on decision to operate with banks

\begin{tabular}{lllllll}
\hline Item & Very high & High & Somewhat high & Not high & Not at all high & Total \\
\hline $\mathbf{1}$ & 25.6 & 65.1 & 9.3 & - & - & $\mathbf{1 0 0}$ \\
$\mathbf{2}$ & 32.1 & 53.6 & 14.3 & - & - & $\mathbf{1 0 0}$ \\
$\mathbf{3}$ & 11.7 & 29.2 & 36.7 & 20.8 & 1.7 & $\mathbf{1 0 0}$ \\
$\mathbf{4}$ & 15.2 & 41 & 36.2 & 6.7 & 1 & $\mathbf{1 0 0}$ \\
Total & $\mathbf{8 4 . 6}$ & $\mathbf{1 8 8 . 9}$ & $\mathbf{9 6 . 5}$ & $\mathbf{2 7 . 5}$ & $\mathbf{2 . 7}$ & $\mathbf{4 0 0}$ \\
\hline
\end{tabular}

Source: field data, 2012. 
1) Extent of Adverts' influence on respondents to operate with their banks

2) Extent of Adverts' influence on others to operate with their banks

3) Extent of banks undertaking advertisement at all (whether banks advertise at all)

4) Extent to which banks advertisements have any positive link with patronage of products and services

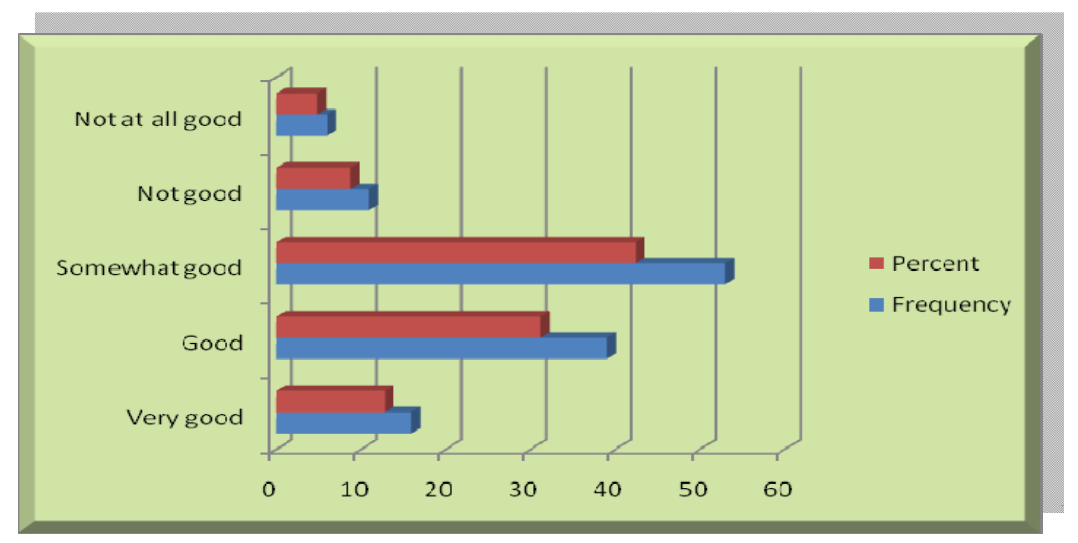

Figure 4. Impression about bank advertisement in the country in general

Source: field data, 2012

When respondents were asked about their general impression on banks' advertisements, $12.8 \%$ said it was very good; $31.2 \%$ opined it was good whilst $42.4 \%$ posited it was somewhat good. However, $8.8 \%$ insisted it was not good whilst $4.8 \%$ pointed it was not good at all. The general conclusion here is that bank advertisement ranges from basically somewhat good to it is good.

Comparing the two, the respondents indicated that as far as advertisements are concerned, universal banks are by far ahead of the rural banks with percentage of $92.2 \%$ and $7.8 \%$ for universal banks and rural banks respectively.

Table 10. Most advertised banks

\begin{tabular}{lll}
\hline Item & Frequency & Percent \\
\hline Rural banks & 10 & $\mathbf{7 . 8}$ \\
Universal banks & 119 & $\mathbf{9 2 . 2}$ \\
Total & $\mathbf{1 2 9}$ & $\mathbf{1 0 0 .}$ \\
\hline
\end{tabular}

Source: field data, 2012.

\subsection{Challenges of the Bank Advertisements}

Responding to the problems faced respondents regarding bank advertisement in the country $31.1 \%$ of respondents had no comments, $41.0 \%$ said bank advertisements in the country are not widespread as expected. $17.2 \%$ advertisements do not target market women, some $6.6 \%$ were worried that advertisements are mostly on TV and internet so rural dwellers may not assimilate the information whilst $4.1 \%$ think the adverts are not clear for their consumption.

Table 11. Problems the respondents have with the bank's advertisement in Ghana

\begin{tabular}{lll}
\hline Column1 & Frequency & Percent \\
\hline No comment & 38 & 31.1 \\
Not available & 50 & 41 \\
Market women are not targeted or considered & 21 & 17.2 \\
Adverts are not clear & 5 & 4.1 \\
Total & 122 & 100 \\
\hline
\end{tabular}

Source: field data, 2012. 
Suggesting the most possible ways of addressing and improving the challenges confronting banks advertisement, $13.6 \%$, indicated that they should introduce and advertise products that benefit the broad spectrum of the population, $50.8 \%$ of respondents said advertisements should be undertaken extensively. Some $9.3 \%$ were of the view that banks should undertake persuasive advertisements whilst $2.5 \%$ suggested the use of local languages in advertising.

Table 12. Suggesting ways of addressing and improving the challenges in banks adverts

\begin{tabular}{lll}
\hline Column1 & Frequency & Percent \\
\hline They should introduce products that benefits a broad section of people & 16 & 13.6 \\
Should make persuasive advertisements & 11 & 9.3 \\
No comment & 19 & 16.1 \\
Make adverts extensive and expansive & 60 & 50.8 \\
Not available & 9 & 7.5 \\
Use of local language & 3 & 2.5 \\
Total & $\mathbf{1 1 8}$ & $\mathbf{1 0 0}$ \\
\hline
\end{tabular}

Source: field data, 2012.

\subsection{Correlation}

The main objective of the study was to establish the relationships between the effects of advertisement and the patronage of bank products and services. To help achieve the main objective, correlation analysis was performed. From the results, there is no correlation at all between Advertisement and Patronage of products and services of banks at (.404).

Table 13. Correlation between advertisement and patronage of products and services of banks

\begin{tabular}{|c|c|c|c|}
\hline Variables & Correlations & Advertisement & $\begin{array}{l}\text { Patronage of products } \\
\text { and services of banks }\end{array}$ \\
\hline \multirow[t]{3}{*}{ Advertisement } & Correlation & 1 & .404 \\
\hline & Sig. (2-tailed) & & .108 \\
\hline & $\mathrm{N}$ & 96 & 17 \\
\hline \multirow{3}{*}{$\begin{array}{l}\text { Patronage of products } \\
\text { and services of banks }\end{array}$} & Correlation & .404 & 1 \\
\hline & Sig. (2-tailed) & .108 & \\
\hline & $\mathrm{N}$ & 17 & 30 \\
\hline
\end{tabular}

Source: field data, 2012.

Table 14. Mean and standard deviation of advertisement and patronage of products and services of banks

\begin{tabular}{llllll}
\hline Variables & Mean & $\begin{array}{l}\text { Std. } \\
\text { Deviation }\end{array}$ & Df & R & P \\
\hline $\begin{array}{l}\text { Advertisement } \\
\text { Patronage of products and services }\end{array}$ & 5.4479 & .83186 & & & \\
\hline
\end{tabular}

Source: field data, 2012.

From Table 14, the participants' advertisement score $(\mathrm{M}=5.4479, \mathrm{SD}=.83186)$ had no significant relationship with Patronage of services score $(\mathrm{M}=14.4333, \mathrm{SD}=3.01357), \mathrm{p}$-value $=.108$. This is found outside the acceptance region of $\mathrm{p}=0.05$. This implies that there is no difference at all between advertisement and patronage of products and services.

\subsection{Regression}

The study also aimed at finding the effect of Predictors (independent variables): I just saw the bank in my community, word of mouth recommendation, message about the bank on the Radio, message about the bank on $\mathrm{TV}$, message about the bank in the newspapers on the dependent variable (patronage of products and services of 
banks). Multiple Regressions was performed to analyze the five predictors (independent variables). Table 15 shows descriptive statistics of the means and standard deviations of the effects of adverts on promoting banks operations.

Table 15. Means and standard deviations of participants' effect of advert on promoting banks operations

\begin{tabular}{llll}
\hline Variable & Mean & $\begin{array}{l}\text { Std. } \\
\text { Deviation }\end{array}$ & N \\
\hline Effects of adverts & 14.9412 & 2.60937 & 17 \\
Message about the bank on TV advertisement & 1.5882 & .50730 & 17 \\
Message about the bank on Radio & 1.4706 & .51450 & 17 \\
Message about the bank in the Newspaper & 1.8824 & .33211 & 17 \\
Somebody told me about the bank & 1.6471 & .49259 & 17 \\
I just saw the bank in my community & 1.8235 & .39295 & 17 \\
\hline
\end{tabular}

Source: field data, 2012.

Table 16 shows the summary of the model of the regression that was performed. The table indicates how much of the variance in the dependent variable (Effects of adverts) that is explained by the model which included Predictors: (Constant), I just saw the bank in my community, somebody told me about the bank, message about the bank on Radio, message about the bank on TV, message about the bank in newspapers. From the table, the value is .493. Expressed as a percentage, it means that the model (the totality of the effect of all the predictors) account for .493 percent of the variance in the participants' effects of adverts. In other words, the extent to which all the predicting variables can contribute to the explanation of effects of adverts is $49.3 \%$.

Table 16. Model summary showing the variance of the model

\begin{tabular}{llllllll}
\hline Model & R & R Square & $\begin{array}{l}\text { Adjusted } \\
\text { Square }\end{array}$ & $\begin{array}{l}\text { R } \\
\text { Std. Error of the } \\
\text { Estimate }\end{array}$ & F & Sig. \\
\hline $\mathbf{1}$ & $.702^{\mathrm{a}}$ & .493 & .263 & 2.24028 & 2.141 & .136 \\
\hline
\end{tabular}

a. Predictors: (Constant), I just saw the bank in my community, somebody told me about the bank, message about the Radio, message about the TV advertisement, message about the bank on Radio

b. Dependent Variable: Effects of adverts

Table 16 also shows the significance of the model variance $(49.3 \%)$. The table shows a significance effect of the model, $\mathrm{F}_{(131)}=2.141, \mathrm{p}=.136$. This shows the effect of the predictors (independent variables) on the dependent variable (Effects of adverts). This means that the $49.3 \%$ variance of the model was not significant enough to affect the participants' general effects of adverts. It must be born in mind that, according to the results, the total contribution of the means by which the banks reach their customers (advertisement) is not statistically significant.

The results of the regression analysis performed according to the study variables are presented in Table 17 . This shows the outcome of each of the independent variables on the dependent variable.

Table 17. Results of the regression analysis of the study variables

\begin{tabular}{|c|c|c|c|c|c|}
\hline & \multicolumn{2}{|c|}{$\begin{array}{l}\text { Unstandardized } \\
\text { Coefficients }\end{array}$} & \multirow{2}{*}{$\begin{array}{l}\text { Standardized } \\
\text { Coefficients } \\
\text { Beta } \\
\end{array}$} & \multirow[t]{2}{*}{$\mathbf{T}$} & \multirow[t]{2}{*}{ Sig } \\
\hline & $\mathbf{B}$ & Std. Error & & & \\
\hline (Constant) & 1.814 & 4.561 & & .398 & .698 \\
\hline TV advert & 2.113 & 1.232 & .411 & 1.716 & .114 \\
\hline Radio advert & -.865 & 1.247 & -.171 & -.694 & .502 \\
\hline Newspaper advert & 3.612 & 1.970 & .460 & 1.833 & .094 \\
\hline Info from somebody & 1.916 & 1.247 & .362 & 1.537 & .152 \\
\hline Bank in community & .597 & 1.614 & .090 & .370 & .719 \\
\hline
\end{tabular}

a. Dependent Variable: Effects of adverts 
As indicated above, table 17 shows the contribution of each of the variables included in the model to the prediction of the dependent variable. This is indicated in the Beta under Standardized Coefficients. From the table, the largest beta coefficient is $-.460(46.0 \%)$, which is for newspaper advert. This means that newspaper advertisement makes the largest contribution to explaining the dependent variable (effect of advert on promoting banks operations). With the beta coefficient of .411 (41.1\%), TV advert makes the second largest contribution to explaining the s effect of advert on promoting banks operations, followed by Info from somebody with a beta coefficient of 362 (36.2\%). The beta value of Radio advert is -.171 (17.1\%) slightly lower than the previous others, indicating that it made a very small of a contribution to explaining the dependent variable. The lowest of all is "bank in the community" which had a beta value of.090 (09.0\%) and thus, making the least of the contribution of the prediction to the effect of advert on promoting banks operations.

Also, the values in the Sig (probability) column tell whether each of the variables under study makes a statistically significant contribution to the equation. That is, whether the beta values (or percentages) indicated is significant enough to affect the effect of advert on promoting banks operations. If the Sig value is less than .05 , then the variable is making a significant unique contribution to the prediction of the dependent variable. If greater than .05 , then it can be concluded that the variable is not making a significant unique contribution to the prediction of effect of advert on promoting banks operations.

As noted earlier from the results presented in Table 17, none of the predictors had a significant effect of advert on promoting banks operations. As a result, our final model is a null model; a model with only a constant.

In the first place, the Sig (p- value) for Newspaper advert is .094 , which is more than .05 . This means that Newspaper advert makes no significant unique contribution to explaining the effect of advert on promoting banks operations.

Secondly, TV advert was also found not to be significant at a probability level of .114. This means TV adverts makes no contribution to making banks services and products popular.

Thirdly, "Information from somebody" was also found not to be statistically significant. The significance level (.152) was found to be far higher than the standard .05. Hence, Info from somebody is not a good predictor of the effect of advert on promoting banks operations.

Fourthly, the significant level of .502 for radio was found to be far bigger than the standard .05 . Hence, radio advert does not contribute to effect of advert on promoting banks operations.

Finally, the significant level of .719 for "bank in community" was found to be far bigger than the standard .05. The general conclusion of the customers view about the subject matter of the study is that they do not see banks do advertisements so much about their products and services and that even information they have about them is mostly as a result of somebody telling them or because the banks are in the community and not so much as a result of the adverts made.

\subsection{Analysis of the Staff Respondents of the Banks}

Information from the workers of the banks was acquired after some strenuous efforts. The employees from Merchant Bank were 10.0\% and 6.7\% from Greater Accra and Eastern Region respectively totalling $16.7 \%$ in all. The same percentages were taken from Ghana Commercial Bank for both areas. Respondents from South Akim Rural Bank constituted $13.3 \%$ whilst $50.0 \%$ of them were from Upper Manya Kro Rural bank.

Table 18. Classification of bank according to area

\begin{tabular}{|c|c|c|c|c|}
\hline \multirow[t]{2}{*}{ Banks } & \multicolumn{3}{|l|}{ Area } & \multirow[b]{2}{*}{ Total $(\%)$} \\
\hline & $\begin{array}{l}\text { Greater } \\
\text { Accra (\%) }\end{array}$ & $\begin{array}{l}\text { Eastern } \\
(\%)\end{array}$ & Region & \\
\hline Merchant Bank Ghana Ltd & 10.0 & 6.7 & & 16.7 \\
\hline Ghana commercial bank Ltd & 10.0 & 6.7 & & 16.7 \\
\hline Barclays Bank Ghana Ltd & & 3.3 & & 3.3 \\
\hline South Akim Rural Bank Ltd & & 13.3 & & 13.3 \\
\hline Upper Manya Krobo Rural Bank Ltd & & 50.0 & & 50.0 \\
\hline Total & 20.0 & 80.0 & & 100.0 \\
\hline
\end{tabular}

Source: field data, 2012. 
Overall, 70\% of respondents were drawn from Rural Banks, whilst 30\% were selected from the Universal Banks. Out of this, $20 \%$ of the staff members were in Greater Accra (the national capital), whilst $80 \%$ were in the Eastern Region of the country. Whilst there were no rural banks represented in Greater Accra, $13.3 \%$ universal bank employees were in Eastern Region.

Table 19. Classification of bank according to type

\begin{tabular}{llll}
\hline \multirow{2}{*}{ Area } & \multicolumn{2}{l}{ Type of bank } & \\
\cline { 2 - 3 } & Rural (\%) & Universal (\%) & Total (\%) \\
\hline Accra & 0.00 & 20.0 & $\mathbf{2 0 . 0}$ \\
Eastern Region & 66.7 & 13.3 & $\mathbf{8 0 . 0}$ \\
Total & $\mathbf{7 0 . 0}$ & $\mathbf{3 0 . 0}$ & $\mathbf{1 0 0 . 0}$ \\
\hline
\end{tabular}

Source: field data, 2012.

\subsection{Employees Respondents View on Advertising Issues}

On advertising bank products on television, $76.9 \%$ perceived banks to be advertising with $23.1 \%$ dissenting. Respondents were split in equal measure when it comes to advertising with $50 \%$ supporting and disagreeing respectively. Regarding radio advertisement, 63.6\% agreed as against 36. 4\% opposing. On the part of the newspaper, $76.2 \%$ of the respondents supported newspaper advertisements whilst $23.8 \%$ of them opposed. The issue of word of mouth recommendation, members of staff overwhelmingly endorsed this medium of attracting customers with $90.9 \%$ supporting as against $9.1 \%$ disagreeing. The propinquity of the banks to the community as a mechanism to attracting bank customers also scored high marks with $90.5 \%$ backing this method as opposed to $9.5 \%$ who opposed.

Table 20. Types of advertisement

\begin{tabular}{llll}
\hline Item & Yes (\%) & No (\%) & $\begin{array}{l}\text { Total } \\
(\%)\end{array}$ \\
\hline Do banks advertise? & & & $\mathbf{1 0 0}$ \\
Television Adverts & 76.9 & 23.1 & $\mathbf{1 0 0}$ \\
Radio Adverts & 50 & 50 & $\mathbf{1 0 0}$ \\
Newspaper Adverts & 63.6 & 36.4 & $\mathbf{1 0 0}$ \\
Word of mouth & 76.2 & 23.8 & $\mathbf{1 0 0}$ \\
Banks in the community & 90.9 & 9.1 & $\mathbf{1 0 0}$ \\
Billboards & 90.5 & 9.5 & $\mathbf{1 0 0}$ \\
Fliers & 80 & 20 & $\mathbf{1 0 0}$ \\
Total & 80 & 20 & $\mathbf{8 0 0}$ \\
\hline
\end{tabular}

Source: field data, 2012.

The use of Billboards attracted immense support from respondents with up to $80.0 \%$ believing in its efficacy as against $20 \%$ disagreeing and the same ratio of support of $80.0 \%$ and $20.0 \%$ was for fliers as a means to lure the customers. Members of staff lend strong support to the use of superior customer service to attract customers. This is proved quantitatively by $72.0 \%$ of the staff members intimating that they acquire their customers through good customer care whilst $28.3 \%$ indicated the use of internet banking and SMS alert.

Table 21. Staff description of how they get their clients to know about the banks

\begin{tabular}{lll}
\hline Item & Frequency & Percent \\
\hline Through good customer care & 18 & 72 \\
Internet banking, SMS alert & 7 & 28 \\
Total & $\mathbf{2 5}$ & $\mathbf{1 0 0}$ \\
\hline
\end{tabular}

Source: field data, 2012. 


\section{Conclusion}

The study examines the influence of advertisements on consumer patronage of the products and services of selected banks as its main objective. The focal point of this research is to analyse the degree of influence that advertisements have on the patronage of products and services of selected banks. Literature is reviewed on various concepts of advertising and the impact advertisement has on consumer buying behaviour on bank products and services. In terms of methodology, a survey instrument was used and a sample of 70 respondents from Greater Accra and Eastern Regions of Ghana drawn through both random and purposive sampling technique. Structured questionnaire served as a tool for data collection with quantitative techniques used for data analysis. Two sets of conclusions were arrived at.

From empirical data, majority of respondents who were all bank customers opine that, they conduct business with banks largely as a result of word of mouth recommendation and proximity of banks to their communities and neighbourhoods. In their fervent view, there is a minimal correlation between advertisements and patronage of the products and services of the banks.

Contrary to the views of the customers, the bank managers and employees think that, the rate at which banks are advertising is satisfactory adding that, customers are inspired to do business with the banks based on the advertisement.

Both the customers and the employees agree that sources of information; word of mouth recommendation and the presence of banks in the community serve as strong incentives to do business with a bank than media advertisements-Radio, Television, and Newspaper.

\section{References}

Andrew, W. (1991). Promotional Culture: Advertising, Ideology and Symbolic Expression. London: Sage Publications Ltd.

Bearden, W. O., Ingram T. N., \& LaForge, R. W. (2001). Introduction to Marketing: Principles and Perspectives (2nd ed.).

Belch, E. G., \& Belch, A. M. (2001). Advertising and Promotion (5th ed.). New York: McGraw Hill Irwin.

Ekaete. B. (2010). Role of Advertising in Business Promotion, e-How Discover the expert in you. Retrieved from http://www.ehow.com/about_6538026_role-advertising-business-promotion.html

Ferguson, R., George, A., \& Takane, Y. (1989). Statistical: An Analysis in Psychology and Education (6th ed.). McGraw Hill Book co.

Fill, C. (2005). Marketing Communications Engagement Strategies and Practice (4th ed.). England: Prentice Hall.

Kotler, P. (1996). Marketing Management: Analysis, Planning and Control. Prentice Hall International series in marketing, Germany.

Kotler, P., Wong, V., Saunders, J., \& Armstrong, G. (2004). Principles of Marketing, Financial Times (4th ed.). Prentice Hall.

Mark, A. (1994). Manufacturing consent: Noam Chomsky and the media Montreal. New York: Black Rose Books.

McFall, L. (2004). Advertising: A Cultural Economy. Thousand Oaks, CA: Sage Publications Inc.

Mulvihill, D. F. (1951). Marketing Research for the Small Company. Journal of Marketing, 16(2), 179-183. http://dx.doi.org/10.2307/1247626

Packard, V. (1957). The Hidden Persuaders. New York: D. McKay Co.

Petley, J. (2002). Advertising. North Mankato. Minnesota: Smart Apple Media.

Pickton, D., \& Broderick, A. (1995). Integrated Marketing Communications, Financial Times Management (2nd ed.).

Pickton, D., \& Broderick, A. (2005). Integrated Marketing Communications (2nd ed.). England: Prentice Hall.

Roger, A. K. (2004). Marketing: The CORE Information Center, Southern Methodist University. McGraw-Hill Higher Education. Retrieved from www.mcgraw-hill.com/sites/ DOI:0070043450

Tabachnich, B. G., \& Fidell, S. L. (1996). Using Multivariate Statistics (3rd ed.). New York: Harper Collins.

Young, C. E. (2005). The Advertising Research Handbook, Ideas in Flight. WA: Seattle. 